\title{
PROPERTIES OF STREPTOCOCCUS THERMOPHILUS FERMENTED MILK CONTAINING VARIABLE CONCENTRATIONS OF BIFIDOBACTERIUM LONGUM AND LACTOBACILLUS ACIDOPHILUS
}

\author{
Patrícia Blumer Zacarchenco; Salvador Massaguer-Roig* \\ Departamento de Tecnologia de Alimentos, Faculdade de Engenharia de Alimentos, Universidade Estadual de Campinas, \\ Campinas, SP, Brasil
}

Submitted: May 25, 2004; Returned to authors for corrections: March 21, 2005; Approved: May 08, 2006

\begin{abstract}
Sensory evaluation and analysis of $\mathrm{pH}$, titratable acidity and microbial counts after 1, 7,14 and 21 days of storage of five combinations of lyophilized Bifidobacterium longum and/or Lactobacillus acidophilus added to milk fermented with Streptococcus thermophilus were studied during storage at $4^{\circ} \mathrm{C}$. The taste and acidity sensory attributes were significantly $(\mathrm{P}<0.05)$ perceived as the storage time increased. Favourite combinations contained, initially, Bif. longum and L. acidophilus $\left(10^{8}\right.$ and $10^{7} \mathrm{cfu} / \mathrm{mL}$, respectively) and Bif. longum only $\left(10^{8} \mathrm{cfu} / \mathrm{mL}\right)$. These combinations did not differ significantly among them and neither from the standard fermented milk. The lowest sensory scores and highest titratable acidity values were obtained for fermented milk added of $L$. acidophilus $\left(10^{8} \mathrm{cfu} / \mathrm{mL}\right.$ initial concentration). During the 21 days of storage at $4^{\circ} \mathrm{C}$ the viable cell counts of: Str. thermophilus did not change. Bif. longum viable cells counts kept constant or reduced 1 logarithmic cycle and L. acidophilus reduced 1 or 2 logarithmic cycle. We did not observe inhibition of over-acidification caused by the presence of bifidobacteria or $L$. acidophilus.
\end{abstract}

Key words: Bifidobacterium, Lactobacillus acidophilus, fermented milk, sensory properties

\section{INTRODUCTION}

The use of Lactobacillus acidophilus and bifidobacteria, normal inhabitants of the human intestine, as dietary adjuncts, has been subject of interest of many researchers $(3,4,9)$. According to Dave and Shah (3) yoghurt or yoghurt-like products have been used as the most popular vehicle for incorporation of probiotic organisms.

Saxelin et al. (18) reported that to maintain confidence in probiotic products it is important to demonstrate good survival of the bacteria in food products during their shelf life, associated to a pleasant taste and attractive texture, regardless of the "health message" of the product. The probiotic product must contain minimum values that vary from $10^{5}$ to $10^{7} \mathrm{cfu} / \mathrm{g}$ of probiotic bacteria at use-by date $(4,6,15,16,19)$.
Properties such as growth rate; metabolic rate; proteolitic activity and flavour promotion of several probiotic strains are species specific and success in industrial applications may be obtained through careful management of these factors and tailored manufacturing processes $(6,18)$.

Production of high-quality fermented milk products containing Bifidobacterium spp. and L. acidophilus is, according to Gomes and Malcata (6), a challenge to dairy plants owing to the sensitive character of the microorganisms. Additionally, Dave and Shah (3) reported that it is not feasible to ferment milk using only probiotics, due to the longer fermentation time required to reduce the $\mathrm{pH}$ of milk and to the objectionable taste produced by some probiotic bacterial strains. However, probiotic strains may be used with a support culture, like Str. thermophilus or another yoghurt culture $(17,20)$. *Corresponding Author. Mailing address: Departamento de Tecnologia de Alimentos, FEA, Unicamp, Caixa Postal 6121. 13083-970, Campinas, SP,
Brasil. Tel.: (+5519) 3788-4016, E-mail: salvador@fea.unicamp.br; patyzacarchenco@yahoo.com.br; zacarchenco@ faj.br 
Lourens-Hattingh and Viljoen (9) reported that the probiotic culture may be added prior to fermentation, simultaneously with the conventional yogurt cultures or after fermentation to the product cooled to $4^{\circ} \mathrm{C}$, before packaging. Saxelin et al. (18) did not observe a reduction in the number of probiotic bacteria in some combinations of probiotic and yoghurt cultures, concluding that it is important to select an optimal support culture to obtain good probiotic survival during the shelf life of the product.

Tamime et al. (21) reported that in Europe, United States and East Europe, fermented dairy products contained: (a) Lac. acidophilus, Bifidobacterium spp., Lac. casei sub-specie casei biovar shirota, Lac. GG strain, and/or combinations of these bacteria with common lactic starters; (b) bacteria isolated from human which are able to survive and to grow on the human intestine and to adhere to epithelial intestine cells; (c) more than $10^{6} \mathrm{cfu} / \mathrm{mL}$ or gram of the product (20).

The use of bifidobacteria in cultured milks, according to Medina and Jordano (11), produces some of the following nutritional and technological advantages: i) mild sour taste; ii) limited after acidification; iii) less bitterness; iv) are beneficial as intestinal organisms.

Hoier (7) reported that bifidobacteria produces, during fermentation, acetic and lactic acids at the ratio $3: 2$. So, excessive growth may yield products with vinegar-like taste and aroma. Also, Samona et al. (17) investigated the production of acetic acid and others organic acids during 21 days of storage at $4^{\circ} \mathrm{C}$ of fermented milks prepared with different combinations of two yogurt cultures and Bif. adolescentis, Bif. bifidum and Bif. longum. The acetic acid produced by bifidobacteria, which apparently has a inhibitory effect on Lactobacillus delbrueckii ssp bulgaricus and Streptococcus salivarius subsp. thermophilus, may prevent post-production acidification, according to Samona et al. (17).

The objectives of this research were to study the influence of the Bif. longum and L. acidophilus concentrations, added in the liophilyzed form to a Str. thermophilus fermented milk, on the taste and acidity sensorial atributes, $\mathrm{pH}$, titratable acidity and microbial counts characteristics during 21 days of refrigerated storage.

\section{MATERIALS AND METHODS}

\section{Test organisms}

The following test organisms were used: freeze dried starter cultures of Str. thermophilus TA 559 (ST), L. acidophilus LAC4 (LAC) and Bif. longum BL (BL) from Ezal® - Texel, supplied by Rhodia Food (Paulínia, Brasil).

\section{Culture media and reagents}

The following culture media and reagents were used: (i) Triptone, (ii) bacto bile, (iii) bacto peptone, (iv) agar (Difco,
Detroit, Mi, USA); (v) sucrose, (vi) yeast extract, (vii) $\mathrm{KH}_{2} \mathrm{PO} 4$, (viii) sodium propionate (SIGMA, St. Louis, MO, USA); (ix) lithium chloride (Synth, Diadema, SP, Brasil); (x) Anaerobac (Probac, São Paulo, SP, Brasil); (xi) MRS (Man Rogosa Sharpe) agar (Oxoid, Basingstoke, Hampshire, En); (xii) Skim milk powder (Molico, Nestle, Araçatuba, SP, Brazil).

\section{Starter and intermediate cultures preparation}

Sterile reconstituted skim milk ( $\left.11 \% \mathrm{ST}, 115^{\circ} \mathrm{C} / 10 \mathrm{~min}\right)$ was inoculated with freeze-dried ST in laminar air flow cabinet, fermented to coagulation at $42^{\circ} \mathrm{C}$ and cooled. The $\mathrm{pH}$ of starters and intermediate cultures of ST was on the range of $4.4-4.7$, after 4 hours of incubation at $42^{\circ} \mathrm{C}$.

\section{Fermented milks preparation}

Twenty five liters of heat treated $\left(90^{\circ} \mathrm{C} / 5 \mathrm{~min}\right)$ reconstituted ( $12 \%$ total solids) skim milk was inoculated with $2 \%$ intermediate culture, fermented to aproximate $\mathrm{pH} 4.7$ at $45^{\circ} \mathrm{C}$ and chilled to $38^{\circ} \mathrm{C}$. This $\mathrm{pH}$ was reached around $2 \mathrm{~h} 45 \mathrm{~min}$ of fermentation. The LAC and BL cultures were then added in quantities specified on Table 1, stirred and conditioned into sterilized glass bottles and stored at $4^{\circ} \mathrm{C}$. This experiment was repeted twice for all 6 combinations (see Table 1).

Table 1. Probiotics Initial concentrations of the fermented milks ${ }^{\mathrm{a}}$.

\begin{tabular}{ccc}
\hline Combination & Microorganisms ${ }^{\mathrm{b}}$ & $\begin{array}{c}\text { Initial Probiotics } \\
\text { Concentrations - IPC } \\
\text { (cfu/mL) }\end{array}$ \\
\hline $\mathrm{C} 1$ & $\mathrm{ST}$ & - \\
\hline $\mathrm{C} 2$ & $\mathrm{ST}$ & -- \\
& $\mathrm{BL}$ & $1 \times 10^{8}$ \\
\hline $\mathrm{C} 3$ & $\mathrm{ST}$ & -- \\
& $\mathrm{BL}$ & $1 \times 10^{7}$ \\
$\mathrm{C} 4$ & $\mathrm{LAC}$ & $1 \times 10^{8}$ \\
\hline & $\mathrm{ST}$ & -- \\
& $\mathrm{BL}$ & $1 \times 10^{8}$ \\
$\mathrm{C} 5$ & $\mathrm{LAC}$ & $1 \times 10^{8}$ \\
\hline $\mathrm{C} 6$ & $\mathrm{ST}$ & -- \\
& $\mathrm{BL}$ & $1 \times 10^{8}$ \\
& $\mathrm{LAC}$ & $1 \times 10^{7}$ \\
\hline & $\mathrm{ST}$ & $1 \times 10^{8}$ \\
\hline
\end{tabular}

a: Determined by considering the probiotics counts of LAC and BL presented in the lyophilized powder. These counts were verified using microbiological methods described below. b: ST=Streptococcus thermophilus; $\mathrm{BL}=$ Bifidobacterium longum $; \mathrm{LAC}=$ Lactobacillus acidophilus 
The reconstituted skim milk used at different steps of this research was prepared using skim milk powder (Molico, Nestle, Araçatuba, SP, Brazil) supplied by local markets.

\section{Fermented milks evaluation}

Fermented milks taste and acidity sensorial attributes evaluation, viable cell counts, $\mathrm{pH}$ and titratable acidity determinations were performed at 1, 7, 14 and 21 days of refrigerated storage at $4^{\circ} \mathrm{C}$.

\section{Sensory evaluation}

The sensorial attributes evaluation was performed using the acceptability test methodology with 35 untrained panelists, using a 9-points balanced scale. Each panelist received $30 \mathrm{~g}$ of the samples of the fermented milks described on Table 1 (C1 to C6). The samples were codified and presented to the panelist in randomized order as suggested Meilgaard et al. (12). The sensorial analysis sessions were carried out like described in Meilgaard et al. (12) and Macfie et al. (10).

The data were analyzed by ANOVA, using the Tukey test to evaluate differences among averages and the Statistical Analysis System (SAS 8.02 TS level 02M0). A P value $<0.05$ was considered to be significant.

\section{Microbiological analysis}

Tubes containing $0.1 \%$ sterile peptone water and the samples of fermented milk were homogenized by Vortex shaking. After homogenization, the samples were serial decimally diluted in $0.1 \%$ sterile peptone water, pour plated in ST agar (aerobiosis) at $30^{\circ} \mathrm{C} /$ 48h according to Zacarchenco and Massaguer-Roig (25) for Str. thermophilus, in Bile-MRS agar (aerobiosis) at $37^{\circ} \mathrm{C} / 72 \mathrm{~h}$ according to Vinderola and Reinhemer (22) for L. acidophilus and in LPMRS (lithium-propionate-MRS) agar (anaerobiosis) at $37^{\circ} \mathrm{C} / 72 \mathrm{~h}$ according to Vinderola and Reinhemer (22) and the modifications of Zacarchenco and Massaguer-Roig (26) for Bif. longum.

\section{Determination of the acidity and $\mathrm{pH}$}

The evaluation of $\mathrm{pH}$ was performed with a $\mathrm{pH}$ meter Model PH320 (WTW®) and, the evaluation of the titratable acidity was performed according to AOAC (1), both in triplicate.

\section{RESULTS}

Data from measurements of $\mathrm{pH}$, acidity, average of scores obtained at sensory evaluations and cell counts of fermented milks, performed at 1, 7, 14 and 21 days of storage of two experiments are presented on Tables 2 and 3 .

Tamime et al. (21) reported that commercially produced bifidobacteria starters give more consistent activity than the in house production of liquid cultures which are subject to daily transfers. The experiments were realized by the authors using commercially produced BL and LAC starters.

\section{Sensory evaluation of the taste attribute}

The sensory differences among fermented milks added or not of LAC and BL (combinations) were significantly $(\mathrm{P}<0.05)$ perceived as storage time increased.

At day 1 of refrigerated storage the fermented milks most preferred by the panelists were $\mathrm{C} 1, \mathrm{C} 2$ and $\mathrm{C} 5$ (Table 2) and did not differ $(\mathrm{P}<0.05)$ from each other, in the experiment 1 . These results are similar to those found after 21 days of storage. In the experiment 2 , the favourites combinations were $\mathrm{C} 1, \mathrm{C} 5$ and $\mathrm{C} 3$ although $\mathrm{C} 2$ did not differ $(\mathrm{P}<0.05)$ from these favourites. At day 1 of storage, in the experiment 1, C6 obtained the lowest sensory scores and differed $(\mathrm{P}<0.05)$ from $\mathrm{C} 1$. In the experiment 2, C4 obtained the lowest sensory scores.

At 7 days of refrigerated storage sensory scores of the experiments 1 and 2 showed significant differences $(\mathrm{P}<0.05)$ among favourites combinations (Table 2). In the first experiment the favourites combinations were $\mathrm{C} 5, \mathrm{C} 1$ and $\mathrm{C} 2$ and $\mathrm{C} 3$ was the fourth preferred. Similar results were obtained at 21 days of storage (Table 2). In the other hand, C2, C3 and C5 were the favourites combinations in experiment 2 , while $\mathrm{C} 1$ was the fourth preferred. The most preferred combinations $\mathrm{C} 5$ and $\mathrm{C} 2 \mathrm{kept}$ their positions in the preference order at 14 and 21 days of storage (Table 2) although $\mathrm{C} 1, \mathrm{C} 2, \mathrm{C} 3$ and C5 did not differ significantly $(\mathrm{P}<0.05)$.

It was noted at 7 days of storage that $\mathrm{C} 4$ obtained the lowest sensory scores and differed significantly $(\mathrm{P}<0.05)$ from $\mathrm{C} 5$ in experiment 1 . In experiment 2 , in this same period of storage, $\mathrm{C} 4$ was the least preferred and differed significantly from $\mathrm{C} 2$.

At 14 days of refrigerated storage sensory scores of combinations $\mathrm{C} 5$ and $\mathrm{C} 2$, from experiments 1 and 2, were the most preferred combinations (Table 2). These combinations received similar sensory scores and did not differ significantly $(\mathrm{P}<0.05)$ between each other. They did not differ significantly $(\mathrm{P}<0.05)$ from $\mathrm{C} 1$, the standard fermented milk. The combination $\mathrm{C} 4$ differed significantly $(\mathrm{P}<0.05)$ from $\mathrm{C} 5$ and $\mathrm{C} 2$ and received the lowest sensory scores. Until day $14^{\text {th }} \mathrm{C} 4$ and $\mathrm{C} 6$ did not differ from each other. This differentiation occurred after 14 days of storage.

At 21 days of refrigerated storage sensory scores of the experiments 1 and 2 for the attribute taste showed good similarity (Table 2). The most favourite combinations were C5 and C2. C5 contained BL and LAC (IPC of $10^{8}$ and $10^{7} \mathrm{cfu} / \mathrm{mL}$, respectively) and $\mathrm{C} 2$ contained BL only (IPC de $10^{8} \mathrm{cfu} / \mathrm{mL}$ ). However, C5 and $\mathrm{C} 2$ obtained similar sensory scores and did not differ significantly $(\mathrm{P}<0.05)$. These favourite combinations did not differ significantly $(\mathrm{P}<0.05)$ from $\mathrm{C} 1$, the standard fermented milk. Davidson et al. (4) found similar results in frozen yogurt. The combinations C3 and C6 obtained lowest sensory scores (Table 2). C3 contained BL and LAC (IPC of $10^{7}$ and $10^{8} \mathrm{cfu} \mathrm{mL}^{-1}$, respectively) and C6 contained LAC only (IPC de $10^{8} \mathrm{cfu} / \mathrm{mL}$ ). C6 was significantly $(\mathrm{P}<0.05)$ different from $\mathrm{C} 5, \mathrm{C} 2$ and $\mathrm{C} 1$, obtaining the lowest sensory scores. 
Table 2. Values of $\mathrm{pH}$, acidity and average of scores obtained at sensory evaluations of fermented milks added or not of the BL $\mathrm{BL}^{\mathrm{x}}$ and $\operatorname{LAC}^{\mathrm{x}}$ at days $1,7,14$ and 21 of the storage for processings 1 and 2.

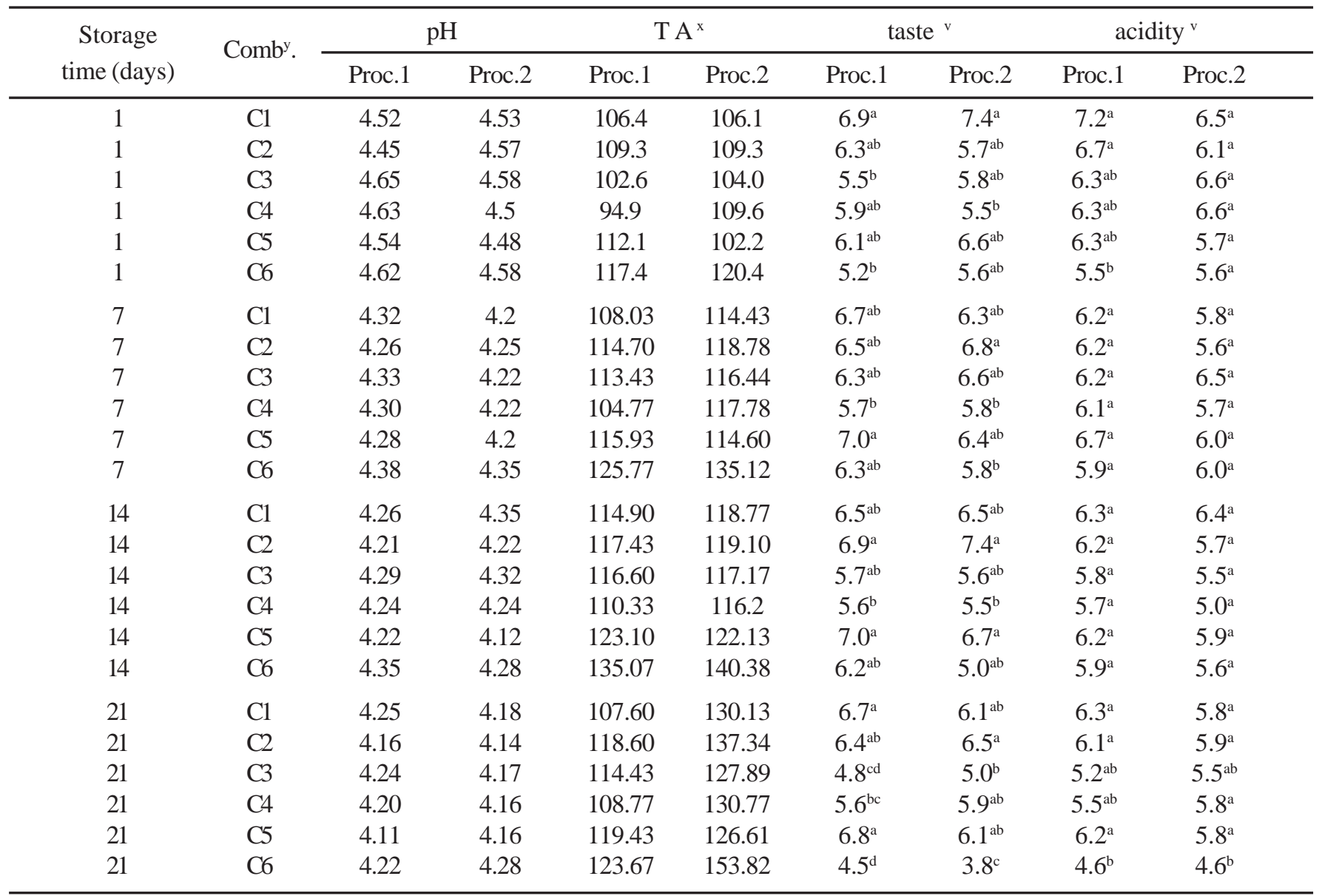

x: BL, LAC and T. A. means, respectively, Bif. longum, L. acidophilus and titratable acidity. y: see Table 1. v: different letters indicate significant differences $(\mathrm{P}<0.05)$ among combinations of the fermented milks.

According to Davidson et al. (4) other authors also have reported that the activity of yogurt starter and probiotic bacteria caused specific changes in the products affecting sensory characteristics and that fermented products cultured with bifidobacteria were different from the yogurts produced with traditional starters.

Baig and Prasad (2) studied the effect of adding Bif. bifidum as a supplementary starter culture on the biochemical, microbiological and organoleptic characteristics of yogurt. These authors reported that supplementation with Bif. bifidum reduced $(\mathrm{P}<0.05)$ the flavour score slightly concluding that the reduction in the flavour score was related to acetic acid production by Bifidobacterium. Also the acetic acid production by different Bifidobacterium strains was evaluated by Ostlie et al. (14).

The differences in the preference order of $\mathrm{C} 3$ and $\mathrm{C} 1$ can be related to others organic acids produced by the $\mathrm{BL}$ and/or LAC, instead of lactic acid, in the fermented milk $\mathrm{C} 3$. The production of larger quantities of acetic acid from $7^{\text {th }}$ day to $14^{\text {th }}$ of storage, for example, could cause sensory differences that panelist could perceive as suggested by Gomes and Malcata (6).

The results presented by Samona et al. (17) showed an increase on the acetic acid concentration at different shelf life periods at $4^{\circ} \mathrm{C}$ of yogurts that contained Bif. adolescentis, Bif. bifidum and Bif. longum. The increase in the acetic acid concentration varied according to probiotic strain and source used of yogurt starter. Some yogurts reached, after 21 days of storage, the double of the acetic acid concentration measured at the day of yogurt processing. Our results regarding sensory preferences, probably, could be explained by the microorganisms behaviors similar to that described by Samona et al. (16). The reduction in the sensory scores of $\mathrm{C} 3$ observed after 7 days, in experiment 1, and after 14 days of storage, in 
experiment 2, could be related to the acetic acid production described by Samona et al. (17).

\section{Sensory evaluation of the acidity attribute}

After 1 day of storage, in the experiment 1, the most preferred fermented milks was $\mathrm{C} 1$ (Table 2). The fermented milk C6 obtained the lowest sensory scores, in experiments 1 and 2, and differed significantly $(\mathrm{P}<0.05)$ from $\mathrm{C} 1$ and $\mathrm{C} 2$. In the experiment 2 , the most preferred fermented milks were $\mathrm{C} 3, \mathrm{C} 4$ and $\mathrm{C} 1$.

At days 14, 7 and 1 of storage the fermented milks obtained acidity sensory scores that did not differ significantly $(\mathrm{P}<0.05)$ (Table 2).

At 21 days of storage sensory scores for the attribute acidity were similar to those of the attribute taste (Table 2). The fermented milks $\mathrm{C} 2, \mathrm{C} 5$ and $\mathrm{C} 1$ obtained the highest scores and did not

Table 3. Values of viable cells counts of the fermented milks added or not of $\mathrm{BL}^{\mathrm{x}}$ and $\operatorname{LAC}^{\mathrm{x}}$ at days $1,7,14$ and 21 of the storage for processings 1 and 2.

\begin{tabular}{|c|c|c|c|c|c|c|c|}
\hline \multirow{2}{*}{$\begin{array}{c}\text { Storage } \\
\text { time (days) }\end{array}$} & \multirow{2}{*}{ Comb ${ }^{y}$. } & \multicolumn{3}{|c|}{ ST } & \multicolumn{2}{|l|}{ LA } & \multirow[t]{2}{*}{$\mathrm{BL}$} \\
\hline & & Proc. 1 & Proc. 2 & Proc. 1 & Proc. 2 & Proc. 1 & \\
\hline 1 & $\mathrm{C} 1$ & $2.0 \times 10^{9}$ & $1.9 \times 10^{9}$ & $-w$ & $-w$ & $-\mathrm{w}$ & $-w$ \\
\hline 1 & $\mathrm{C} 2$ & $2.1 \times 10^{9}$ & $3.0 \times 10^{9}$ & $-^{r}$ & $-\mathrm{r}$ & $1.0 \times 10^{8}$ & $3.7 \times 10^{7}$ \\
\hline 1 & $\mathrm{C} 3$ & $2.0 \times 10^{9}$ & $2.0 \times 10^{9}$ & $3.5 \times 10^{7}$ & $5.3 \times 10^{7}$ & $2.0 \times 10^{7}$ & $4.4 \times 10^{7}$ \\
\hline 1 & $\mathrm{C} 4$ & $2.0 \times 10^{9}$ & $2.1 \times 10^{9}$ & $2.8 \times 10^{7}$ & $4.3 \times 10^{7}$ & $8.5 \times 10^{7}$ & $3.510^{7}$ \\
\hline 1 & $\mathrm{C} 5$ & $2.0 \times 10^{9}$ & $1.8 \times 10^{9}$ & $1.7 \times 10^{7}$ & $2.4 \times 10^{7}$ & $7.4 \times 10^{7}$ & $2.7 \times 10^{7}$ \\
\hline 1 & C6 & $2.3 \times 10^{9}$ & $2.2 \times 10^{9}$ & $3.4 \times 10^{7}$ & $5.4 \times 10^{8}$ & $-\mathrm{s}$ & $-\mathrm{s}$ \\
\hline 7 & $\mathrm{C} 1$ & $2.2 \times 10^{9}$ & $2.3 \times 10^{9}$ & $-w$ & $-w$ & $-w$ & -w \\
\hline 7 & $\mathrm{C} 2$ & $2.2 \times 10^{9}$ & $2.1 \times 10^{9}$ & $-^{r}$ & $-\mathrm{r}$ & $1.9 \times 10^{7}$ & $3.0 \times 10^{7}$ \\
\hline 7 & $\mathrm{C} 3$ & $2.2 \times 10^{9}$ & $2.6 \times 10^{9}$ & $2.9 \times 10^{7}$ & $3.1 \times 10^{7}$ & $9.1 \times 10^{6}$ & $4.5 \times 10^{7}$ \\
\hline 7 & $\mathrm{C} 4$ & $2.3 \times 10^{9}$ & $1.9 \times 10^{9}$ & $2.7 \times 10^{7}$ & $2.0 \times 10^{7}$ & $2.4 \times 10^{7}$ & $3.610^{7}$ \\
\hline 7 & $\mathrm{C} 5$ & $2.1 \times 10^{9}$ & $1.9 \times 10^{9}$ & $1.8 \times 10^{7}$ & $2.0 \times 10^{7}$ & $2.2 \times 10^{7}$ & $4.6 \times 10^{7}$ \\
\hline 7 & C6 & $2.3 \times 10^{9}$ & $2.8 \times 10^{9}$ & $2.9 \times 10^{7}$ & $5.9 \times 10^{7}$ & $-\mathrm{s}$ & $-\mathrm{s}$ \\
\hline 14 & $\mathrm{C} 1$ & $2.4 \times 10^{9}$ & $2.6 \times 10^{9}$ & -w & - w & -w & - w \\
\hline 14 & $\mathrm{C} 2$ & $2.6 \times 10^{9}$ & $2.4 \times 10^{9}$ & $-^{r}$ & $-r$ & $4.0 \times 10^{7}$ & $4.9 \times 10^{7}$ \\
\hline 14 & $\mathrm{C} 3$ & $2.0 \times 10^{9}$ & $2.6 \times 10^{9}$ & $6.7 \times 10^{6}$ & $1.2 \times 10^{7}$ & $2.1 \times 10^{7}$ & $4.4 \times 10^{7}$ \\
\hline 14 & $\mathrm{C} 4$ & $1.9 \times 10^{9}$ & $2.0 \times 10^{9}$ & $9.0 \times 10^{6}$ & $1.5 \times 10^{7}$ & $2.5 \times 10^{7}$ & $3.0 \times 10^{7}$ \\
\hline 14 & $\mathrm{C} 5$ & $2.3 \times 10^{9}$ & $2.0 \times 10^{9}$ & $6.0 \times 10^{5}$ & $6.0 \times 10^{5}$ & $9.0 \times 10^{6}$ & $4.6 \times 10^{7}$ \\
\hline 14 & C6 & $2.4 \times 10^{9}$ & $1.5 \times 10^{9}$ & $1.1 \times 10^{7}$ & $1.8 \times 10^{7}$ & $-\mathrm{s}$ & $-\mathrm{s}$ \\
\hline 21 & $\mathrm{C} 1$ & $2.1 \times 10^{9}$ & $3.1 \times 10^{9}$ & - w & - w & - w & - w \\
\hline 21 & $\mathrm{C} 2$ & $2.0 \times 10^{9}$ & $1.6 \times 10^{9}$ & $-r$ & $-^{r}$ & $2.0 \times 10^{7}$ & $2.7 \times 10^{6}$ \\
\hline 21 & $\mathrm{C} 3$ & $2.0 \times 10^{9}$ & $2.2 \times 10^{9}$ & $4.2 \times 10^{6}$ & $5.1 \times 10^{6}$ & $1.6 \times 10^{7}$ & $5.0 \times 10^{6}$ \\
\hline 21 & $\mathrm{C} 4$ & $2.0 \times 10^{9}$ & $1.4 \times 10^{9}$ & $5.0 \times 10^{6}$ & $4.0 \times 10^{6}$ & $1.3 \times 10^{7}$ & $2.8 \times 10^{6}$ \\
\hline 21 & $\mathrm{C} 5$ & $2.1 \times 10^{9}$ & $2.5 \times 10^{9}$ & $3.3 \times 10^{5}$ & $3.7 \times 10^{5}$ & $1.4 \times 10^{7}$ & $4.4 \times 10^{6}$ \\
\hline 21 & C6 & $2.1 \times 10^{9}$ & $1.8 \times 10^{9}$ & $9.0 \times 10^{6}$ & $7.5 \times 10^{6}$ & $-s$ & $-\mathrm{s}$ \\
\hline
\end{tabular}

x: BL, LAC and ST means, respectively, Bif. longum, L. acidophilus and Str. thermophilus. y: see Table 1. w: - Fermented milk without addition of Bif. longum and L. acidophilus; r and sFermented milk without addition of L. acidophilus and of Bif. longum, respectively. differ from each other. Similarly to the attribute taste, C6 obtained the lowest sensory scores and differed from $\mathrm{C} 2, \mathrm{C} 5$ and $\mathrm{C} 1$ in the two experiments.

The fermented milk C6 was the least preferred by the sensory panelists when evaluating the attributes taste and acidity. C6 showed the highest titratable acidity.

\section{Measurements of $\mathrm{pH}$ and titratable acidity of the fermented milks}

The fermented milk C6 that contained LAC and ST, showed the highest titratable acidity during the storage time in all the measurements performed, in the two experiments. However the C6 fermented milk did not show the lowest $\mathrm{pH}$ which probably is due to differences in the ionization constant, amount and relative proportions of the organic acids produced. According to Shahani, Vakil and Kilara (20) $L$. acidophilus produces lactic acid, acetic acid, benzoic acid, hydrogen peroxide and bacteriocins and microcins. The authors of the current research did not realized separated determination of acetic acid. In the fermented milk C6, ST produced the lactic acid during fermentation and storage and LAC produced additionally to lactic acid other acids like acetic acid, during the storage period.

During the 21 days of the storage period, generally, the fermented milks showed increasing titratable acidity values and decreasing $\mathrm{pH}$ values. Only at experiment 1 , the titratable acidity values were higher at 14 days of storage then at 21 days.

\section{Viable cell counts of the fermented milks}

All the fermented milks showed constant viable cell counts of ST during the 21 days of storage, in the two experiments (Table 3). Oliveira et al. (13) reported similar results for counts of Str. thermophilus in fermented lactic beverages containing probiotic bacteria. However, Vinderola, Mocchiutti and Reinheimer (24) reported that lactic bacteria were inhibited by the probiotic bacteria and vice-versa. These authors stressed the existence of lactic bacteria strains which were not inhibited and the necessity of a careful restriction of the results obtained to the strains studied. 
The viable cell counts of ST in our study showed that the inhibition of ST by the BL and LAC did not occur.

The viable cell counts of BL were kept around $10^{7}$ and $10^{6}$ $\mathrm{cfu} / \mathrm{mL}$ until the $21^{\text {th }}$ of storage at $4^{\circ} \mathrm{C}$. The addition to the ST fermented milk of $10^{7} \mathrm{BL} \mathrm{cfu} / \mathrm{mL}$ instead of $10^{8}$ represents an economic advantage since lest lyophilized material is necessary. The addition of $10^{7} \mathrm{BL} \mathrm{cfu} / \mathrm{mL}$ to ST fermented milk results in viable cells counts of $\mathrm{BL}$ in the final product, until 21 days of storage at $4^{\circ} \mathrm{C}$, which are in agreement to recommended values for health benefits (21).

The diference between BL counts of the experiments 1 and 2 could be related to the sensibility to oxygen of the BL. During the stirring of the fermented milk of the experiment 2 (Table 3) more quantities of oxygen could be added. The sensibility to oxygen of bifidobacteria was related by researchers like Vinderola, Bailo and Reinheimer (23).

The viable cell counts of LAC for fermented milk C5 from 14 days of storage were on the range of $10^{5} \mathrm{cfu} / \mathrm{mL}$ which represents a 2 logarithmic cycles reduction of LAC, since for the production of $\mathrm{C} 5$ were added $10^{7} \mathrm{cfu} / \mathrm{mL}$ of LAC and $10^{8} \mathrm{cfu} / \mathrm{mL}$ of BL. Gregurek (5) reported that counts and the stability of bifidobacteria starter cultures used were higher than those of $L$. acidophilus. Vinderola et al. (24) reported that L. acidophilus was the sole species inhibited by the others tested (Bifidobacterium, Streptococcus and Lb.casei). These authors also reported that $L$. acidophilus is more sensible then bifidobacteria to media like yogurts and acidified milks when considering ranges of the $\mathrm{pH}$ from 3.5 to 4.5. Oliveira et al. (13) also reported a 2 logarithmic cycles reduction of the $L$. acidophilus populations after 28 days of storage at $4^{\circ} \mathrm{C}$ in the presence of ST.

In the fermented milks $\mathrm{C} 3, \mathrm{C} 4$ and $\mathrm{C} 6$ the viable cell counts of LAC were kept above $1 \times 10^{6} \mathrm{cfu} / \mathrm{mL}$ until the and of 21 days of storage

\section{DISCUSSION}

The sensory effects related to the presence of Bif. longum and $L$. acidophilus in the fermented milks were significantly $(\mathrm{P}<0.05)$ perceived while storage time increased. The favourite combinations contained, initially, Bif. longum and L. acidophilus $\left(10^{8}\right.$ and $10^{7} \mathrm{cfu} / \mathrm{mL}$, respectively, C5) and Bif. longum only $\left(10^{8} \mathrm{cfu} / \mathrm{mL}, \mathrm{C} 2\right)$. These combinations did not differ significantly among them and neither from the standard fermented milk (C1). This result represents that it is possible to improve the acceptability of fermented products containing probiotics. The low acceptability of fermented milks containing probiotics were reported by many authors $(2,8,16,20)$.

The lowest sensory scores and highest titratable acidity values was for $L$. acidophilus combination $\left(10^{8} \mathrm{cfu} / \mathrm{mL}\right.$ initial concentration, C6). The sensory scores of $\mathrm{C} 6$ were significantly different $(\mathrm{P}<0.05)$ from $\mathrm{C} 5, \mathrm{C} 2$ and $\mathrm{C} 1$ at 21 days of storage. The fermented milk $\mathrm{C} 6$ showed the highest acidity during the storage time in all the measurements performed. However it was not observed inhibition of over-acidification by bifidobacteria or $L$. acidophilus.

All the fermented milks showed constant viable cell counts of ST during the 21 days of storage. The viable cell counts of BL were kept constant or reduced 1 logarithmic cycle and viable cell counts of LAC were reduced 1 or 2 logarithmic cycle. However, viable cell counts of LAC and BL kept the minimum values that the probiotic product must contain, which vary from $10^{5}$ to $10^{7} \mathrm{cfu} / \mathrm{g}$ of probiotic bacteria, at use-by date like reported by many authors $(4,6,15,16,19)$.

\section{RESUMO}

\section{Propriedades de leites fermentados por Streptococcus thermophilus contendo concentrações variáveis de Bifidobacterium longum e Lactobacillus acidophilus}

Foram estudadas as características sensoriais, de $\mathrm{pH}$ e acidez de cinco combinações de leites fermentados por Streptococcus thermophilus, adicionados de Bifidobacterium longum e/ou Lactobacillus acidophilus liofilizados. Os efeitos sobre as características sensoriais tornaram-se significantes $(\mathrm{p}<0,05)$ com o aumento do tempo de estocagem. As combinações favoritas continham, inicialmente, Bif. longum e L. acidophilus $\left(10^{8}\right.$ e $10^{7} \mathrm{ufc} / \mathrm{mL}$, respectivamente) e Bif. longum apenas $\left(10^{8} \mathrm{ufc} /\right.$ $\mathrm{mL})$. Estas combinações não diferiram significativamente do leite fermentado padrão, nem entre si. As notas mais baixas e os maiores valores de acidez titulável foram apresentados pelo leite fermentado por Streptococcus thermophilus contendo apenas L. acidophilus $\left(10^{8} \mathrm{ufc} / \mathrm{mL}\right.$, concentração inicial). Durante 21 dias de estocagem a $4^{\circ} \mathrm{C}$, as contagens de células viáveis de Str. thermophilus não mudaram, as de Bif. longum mantiveramse constantes ou reduziram em um ciclo logarítmico e, as de $L$. acidophilus reduziram de 1 a 2 ciclos logarítmicos. Não foi observada inibição da pós-acidificação resultante da presença de bifidobactéria ou L. acidophilus.

Palavras-chave: Bifidobacterium, Lactobacillus acidophilus, leite fermentado, análise sensorial

\section{REFERENCES}

1. Association of Official Analytical Chemists. Official Methods of Analysis of AOAC International. 16 ${ }^{\text {th }}$ edition. Washington, vol. 1-2. 1995.

2. Baig, M.I.; Prasad, V. Effect of incorporation of cottage cheese whey solids and Bifidobacterium bifidum in freshly made yoghurt. $J$. Dairy Res., 63, 467-473. 1996.

3. Dave, R.J.; Shah, N.P. Effect of cysteine on the viability of yoghurt and probiotic bacteria in yoghurts made with commercial starter cultures. Int. Dairy J., 7(8/9). 537-545, 1997. 
4. Davidson, R.H.; Duncan, S.E.; Hackney, C.R.; Eigel, W.N.; Boling, J.W. Probiotic culture survival and implications in fermented frozen yogurt characteristics. J. Dairy Sci., 83(4), 666-673, 2000.

5. Gregurek, L. Effect of level of starter culture on viability of probiotic bacteria in yoghurts. Mljekarstvo, 49(1), 3-8, 1999.

6. Gomes, A.M.P.; Malcata, F.X. Bifidobacterium spp. and Lactobacillus acidophilus: biochemical, technological and therapeutical properties relevant for use as probiotics. Trends Food Sci.Technol., 10(4/5), 139-157, 1999.

7. Hoier, E. Use of probiotics starter cultures in dairy products. Food Australia, 44, 418-420, 1992.

8. Lankaputhra, W.E.V.; Shah, N.P.; Britz, M.L. Survival of bifidobacteria during refrigerated storage in the presence of acid and hydrogen peroxide. Milchwissenchaft, 51(2), 65-69, 1996.

9. Lourens-Hattingh, A.; Viljoen, B.C. Yogurt as probiotic carrier food. Int. Dairy J., 11(1/2), 1-17, 2001.

10. Macfie, H.J.; Bratchell, N.; Greenhoff, K.; Vallis, L.V. Designs to balance the effect of order presentation and first-order effects in hall tests. J. Sens. Stud., 4(2), 129-148, 1989.

11. Medina, L.M.; Jordano, R. Survival of constitutive microflora in commercially fermented milk containing bifidobacteria during refrigerated storage. J. Food Prot., 56(8), 731-733. 1994.

12. Meilgaard, M.; Civille, G.V.; Carr, B.T. Controls for tests room, product, and panel; Attribute difference tests: How does attribute X differ between samples; Affective tests: consumer tests and in-house panel acceptance tests; Basic statistical methods; Guidelines for choice of technique. In: M. Meilgaard, G.V. Civille, B.T. Carr, Sensory evaluation techniques, (pp. 23 36, 99 122, 231 304, 337 344) London: CRC Press Inc. 1999.

13. Oliveira, M.N.; Sodini, I.; Remeuf, F.; Tissier, J.P.; Corrieu, G. Manufacture of fermented lactic beverages containing probiotic cultures. J. Food Sci., 67(6), 2336-2341, 2002.

14. Ostlie, H.M.; Helland, M.H.; Narvhus, J.A. Growth and metabolism of selected strains of probiotic bacteria in milk. Int. J. Food Microbiol., 87(1-2), 17-27, 2003.

15. Ouwehand, A.C.; Salminen, S.J. The health effects of cultured milk products with viable and non-viable bacteria. Int. Dairy J., 8(9), 749-758, 1998.
16. Rybka, S.; Kalaisapathy, K. Effect of freeze drying and storage on the microbiological and physical properties of AB-yoghurt. Milchwissenchaft, 52(7), 390-394, 1997.

17. Samona, A.; Robinson, R.K.; Marakis, S. Acid production by bifidobacteria and yoghurt bacteria during fermentation and storage of milk. Food Microbiol., 13(4), 275-280, 1996.

18. Saxelin, M.; Grenov, B.; Svensson, U.; Fondén, R.; Reniero, R.; Mattila-Sandholm, T. The technology of probiotics. Trends Food Sci. Technol., 10(12), 387-392, 1999.

19. Shah, N.P. Isolation and enumeration of bifidobacteria in fermented milk products: A review. Milchwissenchaft, 52, 2, 72-76. 1997.

20. Shahani, K.M.; Vakil, J.R.; Kilara, B.A. Natural antibiotic activity of Lactobacillus acidophilus and bulgaricus. II Isolation of acidophilin from L. acidophilin. Cult. Dairy Prod. J., 12(2), 8-11, 1976.

21. Tamime, A.Y.; Marshall, V.M.E.; Robinson, R.K. Microbiological and technological aspects of milks fermented by bifidobacteria. $J$. Dairy Res., 62(1), 151-187, 1995.

22. Vinderola, C.G.; Reinheimer, J.A. Int. Dairy J. Culture media for the enumeration of Bifidobacterium bifidum and Lactobacillus acidophilus in the presence of yoghurt bacteria. Int. Dairy J., 9(8), 497-505, 1999.

23. Vinderola, C.G.; Bailo, N.; Reinheimer, J.A. Survival of probiotic microflora in Argentinian yoghurts during refrigerated storage. Food Res. Int., 33(2), 97-102, 2000b.

24. Vinderola, C.G.; Mocchiutti, P.; Reinheimer, J.A. Interactions among lactic acid starter and probiotic bacteria used for fermented dairy products. J. Dairy Sci., 85(4), 721-729, 2002

25. Zacarchenco, P.B.; Massaguer-Roig, S. Enumeration of Streptococcus thermophilus in the presence of Bifidobacterium longum and Lactobacillus acidophilus - effect of incubation temperature and atmospheric conditions. Milchwissenchaft, 59(7/8), 370-372, 2004.

26. Zacarchenco, P.B.; Massaguer-Roig, S. Differential enumeration of Bifidobacterium longum and Lactobacillus acidophilus in the presence of Streptococcus thermophilus. Milchwissenchaft, 59(5/ 6), 258-261, 2004 